\title{
Ženski pari moških poimenovanj v slovenskem knjižnem jeziku 16. stoletja
}

\author{
Majda Merše \\ nštitut za slovenski jezik Frana Ramovša, ZRC SAZU, Novi trg 2, \\ SI-1000Ljubljana,majda.merse@guest.arnes.si
}

\begin{abstract}
$\mathrm{V}$ prispevku je zarisan obseg rabe feminativov v slovenskem knjižnem jeziku 16. stoletja. Predstavljene so osnovne pomenske skupine feminativov ter načini njihove tvorbe. Ženski pari moških poimenovanj so primerjalno z moškimi preverjeni glede pomenske skladnosti in glede pogostosti rabe. Predstavljene in vzročno pojasnjene so skupine samo moških in samo ženskih poimenovanj. Opozorjeno je tudi na način izbire zastopnikov skupin, sestavljenih iz moških in ženskih členov.
\end{abstract}

SCN I/1 [2008], 30-52

The paper discusses the usage of feminine designations in $16^{\text {th }}$ century standard Slovenian by presenting their basic semantic groups and formational patterns. Feminine pairs of masculine designations, in comparison with masculine pairs, are examined based on semantic symmetry and the frequency of use. The paper presents and causally explains groups of just masculine and just feminine designations while discussing the manner in which representatives of groups composed of masculine and feminine elements were selected.

Ključne besede: slovenski knjižni jezik 16. stoletja, ženski pari moških poimenovanj, besedotvorje, skupine parnih poimenovanj

Key words: $16^{\text {th }}$ century Slovene literary language, feminine pairs of masculine designations, word formation, groups of pairs designations

0 Poimenovalne potrebe, ki so se kazale pri prevajanju svetopisemskih in drugih verskih besedil, pa tudi pri pisanju samostojnejših, prevodno manj ali povsem neodvisnih del, so slovenske protestantske pisce 16. stoletja spodbudile tudi $\mathrm{k}$ iskanju in tvorbi ženskih parov moških (lastno- in občnoimenskih) poimenovanj. ${ }^{1}$

\footnotetext{
${ }^{1}$ O obojespolnih poimenovanjih v slovenskem jeziku od Brižinskih spomenikov do začetka slovenskega knjižnega jezika prim. Pogorelec 1997: 6-7.
} 
Omembe v Bohoričevi slovnici kažejo, da so t. i. feminativi v tedanji jezik(osl) ovni zavesti živeli kot posebna besedotvorno-pomenska kategorija. Na različnih mestih slovnice navedeni pari kot kojn - kojnka (RoIs - RöICin), lev - levinja, psič - psičica ali psička, Lamberger/Lambergar - Lambergarica, Lublančič - Lublančica ali Lublanšica itd. ${ }^{2}$ izkazujejo tudi najproduktivnejše tvorbene modele ženskih parov v slovenskem knjižnem jeziku 16. stoletja. Navedeni zgledi kažejo na izpeljavo iz lastnoimenskega in občnoimenskega moškega poimenovanja, na tvorbo iz prevzetega in iz domačega samostalnika, na izpeljavo s tvorbeno specializiranimi obrazilnimi morfemi (npr. -ica, -inja, -ka) ter s hkratno glasoslovno premeno, nastalo na morfemskem stiku, ali brez nje.

1 Čeprav ženski pari ne spremljajo vseh moških poimenovanj, je tudi pri njih mogoče razlikovati dve osnovni skupini: redka lastnoimenska (npr. Egipter Egipterica, Jud - Judinja) in številna občnoimenska poimenovanja, ki jih je mogoče nadalje členiti na več podskupin. Mednje spadajo pari, ki označujejo poklicna poimenovanja (npr. apotekar/apoteker - apotekarica, ${ }^{3}$ kuhar - kuharica, kruhapek - kruhapekinja, mlinar - mlinarica), v okviru teh tudi parna poimenovanja, ki označujejo položaje v družbeni strukturi (npr. cesar - cesarica, kralj-kraljica, kraljič - kraljičica, firšt - firština), parna poimenovanja vršilcev različnih dejavnosti (npr. besednik - besednica ${ }^{4}$ ) in nosilcev lastnosti, parna poimenovanja sorodstvenih in drugih razmerij (npr. oča - mati, sin-hči, brat - sestra, preded - prebaba; boter - botra itd.), živalska poimenovanja $($ golob - golobica $)$ itd.

1.1 Na ženske pare moških poimenovanj znotraj pomensko zaokrožene skupine delujočih oseb, ki opravljajo različne poklice, je bilo že opozorjeno (Merše 2007). Mednje spadajo tudi naslednji pari: ključar - ključarica, kmet/ kmetič - kmetica, kramar/kramer - kramarica, mlinar - mlinarica, ošter oštericaloštarica, šulmojster - šulmojstrica,${ }^{5}$ žnidar - žnidarica itd. Večina od njih je bila značilna tudi za slovensko stvarnost 16. stoletja in pri večini so prevladovale omembe moških členov.

${ }^{2} \mathrm{~V}$ Bohoričevi slovnici navedene feminative so opazili številni jezikoslovci, ki so pisali o slovnici: npr. Kolarič 1971: 50, Toporišič 1987: 311, Ahačič 2007: 119-120.

${ }^{3}$ Poimenovanja apotekarica, kuharica in kruha pekinja so v Bibliji omenjena v nizu izrazito ženskih poklicev in dejavnosti: npr. Vafhe Hzhere pak bo on jemal, de bodo Apotekarice, Kuharice, inu kruha pekine (DB 1584: I, 153b). Dejavnosti vršilk poklicev so ugotovljive iz sobesedilnih rab ženskih poimenovanj, v primeru prekrivnih dejavnosti pa tudi iz omemb moških poimenovanj. Dejavnost apotekarice je npr. ugotovljiva iz sobesedilnih rab večkrat omenjanega apotekarja (ukvarja se z gojenjem in obdelavo zdravilnih in dišavnih rastlin (žlahtnega korenja) ter s prodajo zdravil (arcnij) in pripravkov).

${ }^{4}$ Vidovič Muha (1997: zlasti 75-76) govori pri tvorbi parov tipa besednik-besednica (npr. grešn-ical-ik) o vzporedni (besedotvorni) podstavi za poimenovanje žensk in moških.

${ }^{5}$ Par šulmojster - šulmojstrica sobesedilno dopolnjuje navedba para oseb ženskega in moškega spola, ki se učijo: šularec - šularica (prim. Narat 1996: 268-269). 
Med najbolj uveljavljena parna poimenovanja, ki so bila trdna sestavina slovenske stvarnosti 16. stoletja, spadata npr. kmet in kmetica, čeprav je kmet $\mathrm{z}$ različico kmetič pogosto omenjan, kmetica pa le po enkrat $\mathrm{v}$ dveh delih: $\mathrm{v}$ MD 1592 in v TPo 1595. Npr. Bäwrin. (Deutfch.) ruftica. (Latinè.) kmetiza. (Windifch.) villana, contadina (Italicè.) (MD 1592: B2b). Tako kmet kot kmetica opravljata isto delo: obdelujeta zemljo in opravljata kmečka opravila. Tudi pri parih mlinar in mlinarica ter kramar/kramer in kramarica je mogoče predvidevati opravljanje iste dejavnosti. V obeh primerih pogostnostno prevladujejo omembe moškega para: v DB 1584 sta omenjena mlinar (dvakrat) in mlinarica (enkrat), Megiser pa v obeh slovarjih navaja le mlinarja. Tudi pri parih šulmojster in šulmo(j)stica ter kramar/kramer - kramarica prevladuje moški par. Šulmojstrica je omenjena v KPo 1567 , zatem pa v ponovni Juričičevi izdaji istega dela postile. Kramarica se v ne vedno najbolj obvestilnem sobesedilu pojavlja kar v štirih delih: v DB 1584 in v treh Trubarjevih biblijskih prevodih. Npr. Lydia, ena Kramariza, veruje v'Criftufa (DB 1584: I,)((1)IIIa).

Veččlensko skupino sestavljajo poimenovanja moškega in ženskega spola, ki označujejo izdelovanje oblačil in hkrati pokrivajo medsebojno povezane dejavnosti, kot so krojenje in šivanje: žnidar in žnidarica, šivilja, šivkinja in mojškra ter iz hrvaščine prevzeti kreač oz. krejač. ${ }^{6}$ Poimenovanja, ki so domnevno zbrana iz (geografsko) različnih okolij rabe, so glede na slovarsko umestitev sopomenska, čeprav bi njihovo različnost delno lahko opravičevalo tudi opravljanje deljenih delovnih obveznosti. Šivilja, šivkinja in mojškra se npr. pojavljajo kot slovarske ustreznice za nemško Neherin (MD 1592: K6a), žnidarja in žnidarico pa je sobesedilno uporabil tudi Trubar, čeprav omembi ne prinašata natančnejših podatkov o delokrogu moškega in ženskega vršilca poklica. ${ }^{7}$ Skupina izkazuje mešano sestavo tudi glede na izvor.

1.1.1 Za vsa ključna poimenovanja svetne oblastne strukture obstajajo parna poimenovanja: cesar - cesarica, kralj - kraljica, firšt - firština, ${ }^{8}$ knez - kneginja, rihtar - rihtarica ${ }^{9}$ itd. Ob kralju in kraljici se pojavljata še para, ki poimenujeta mlajše člane kraljeve družine: kraljič - kraljičica ter kraljiček

${ }^{6}$ Prim. Schneider (Deut $\mathrm{fch}$.) fartor. (Latinè.) shnidar, Cr: kreazh. (Windifch.) sartore, ripezzatore, racconciatore de vefti. (Italicè.) (MD 1592: N5a).

${ }^{7}$ Prim. SVETNIKI /.../ zhes Shnidarie S. Gutman (TC 1575: 273); Criftus nei taku gori vftal od fmerti, koker ie Lazarus /... / oli te Vduue Syn /.../ oli tiga Shulmoiftra Szhy /.../ oli ta Shnidariza Dorcas (TR 1558: I, 4a).

${ }^{8}$ Firština se v Bibliji, kjer je izpričana, pojavlja neodvisno od firšta. Med ženskim in moškim poimenovanjem je le slovnična, to je spolska razlika, sicer sta sopomenski. Npr. Inu od letiga dne tudi taku poreko te Firfhtine v'Perfij, inu v'Medij, k'vfém Viudom tiga Krajla (DB 1584: I, 262b) - So werden nu die Fürstinnen in Persen vnd Meden auch so sagen zu allen Fürsten des Königs (LB 1545: 902); Sarai fe rezhe, moja Gofpa: Sara pak Gofpa, firfhtina, satu ker je ona iméla nikar le eniga temuzh veliku folkou Gofpa inu Mati biti (DB 1584: I, 10b).

${ }^{9}$ Pri rihtarju in redkeje navajani rihtarici ne gre vedno za poklicno opravljanje dejavnosti. Pri biblijski osebi Debóri je bila npr. sposobnost razsojanja povezana z modrostjo in $\mathrm{s}$ preroškimi močmi: npr. VTemiftim zhaffu je bila Rihtariza v'Israelu ta Prerokina Debora 
in kraljička. ${ }^{10}$ Med parna poimenovanja, ki se nanašajo na poklice svetnega značaja, spadata tudi splošno razširjeni berič s Trubarjevo glasoslovno različico birič in žensko poimenovanje berička, ki je navedeno samo v TA 1566, kjer zaključuje (abecedno uvrščeni) tričlenski niz besed na črko B (Barbara brat berizhka (TA 1566: A3a)). Tudi pomensko razmerje členov para ribič - ribička ni določljivo, saj se tudi ribička pojavlja samo v abecedariju in na seznamu besed, ki se začenjajo na črko R. Ob gospodarju, rabljenem v osnovnem pomenu 'lastnik materialnih dobrin', ${ }^{11}$ nastopa tudi gospodinja, ki se rabi predvsem v dveh pomenih: 'ženska, ki opravlja ali vodi domača, hišna dela' in kot 'gospodarjeva žena'. Med uveljavljene pare se uvrščata tudi poimenovanji gospod-gospa. Ženskemu členu se kot sopomensko poimenovanje tujega izvora pridružuje frava, ki je izpričana v TPo 1595, nastopa tudi kot sestavina besednih seznamov iz Trubarjevih prvih abecedarijev (iz leta 1550 in 1555), kot narečna (koroška) sopomenka gospe je navedena $\mathrm{v}$ drugem registrskem stolpcu DB 1584, z oznako Carn. pa jo navajata tudi oba Megiserjeva slovarja: Fraw. (Deutfch.) Domina. (Latinè.) Gospá, Carn: Frava. (Windifch.) Signora, Madama (Italicè.) (MD 1592: Ea). Moški in ženski predstavnik mlajšega rodu sta poimenovana kot gospodec (v KPo 1567) ali gospodičič, ki je bil spološno znan, in gospodična, ki se je prvič pojavila v DB 1584. Glede na pogosto izkazano vzporedno rabo posebej izstopata tudi hlapec in dekla.

1.1.2 Obsežno skupino sestavljajo večinoma izglagolska poimenovanja moških in ženskih vršilcev različnih dejavnosti: bojnik - bojnica (obstaja velika razlika v pogostosti rabe: bojnica je npr. zapisana enkrat samkrat (Sdaj pak ti bojniza, pèrpraulaj Se: Sakaj nas bodo oblegli (DB 1584: II, 117b) - Aber nu du Kriegerin / rüste dich / Denn man wird vns belagern (LB 1545: 1622), kar omogoča uresničitev enega samega pomena, bojnik pa je uporabljen pogosto, $\mathrm{v}$ velikem številu del in z razširjenim pomenskim spektrom. Poleg pomena 'bojevnik, vojščak' izkazuje tudi pomen 'ubijalec, morilec' (npr. Inu vfi Bojniki morajo puftiti roke pafti (DB 1584: I, 298b) - Vnd alle Krieger müssen die Hand lassen sincken (LB 1545: 1030); Sakai pravi, Pravizhan osdravlienik /.../? Kàr ne pride fàrdito, kako ie bil /.../ pèrfhal /.../ h'Kainu k'boizu alli boiniku fvoiga brata Abela (KPo 1567: XII)). Na vršilce obeh spolov kažeta tudi pogosto omenjana samostalnika coprnik-coprnica. ${ }^{12} \mathrm{~S}$ splošno rabljenim moškim poimenovanjem delavec, ki ga le v TC 1575 spremlja po ustaljenem

(DB 1584: I, 134b) - V tistem času je Izraelu sodila Debóra, Lapidótova žena, žena prerokinja (SP 1996: 305).

${ }^{10}$ Kraljička, ki je ob kraljičici navedena v BH 1584, se zaradi manjše uveljavljenosti besedotvornega obrazila uvršča med poskusne tvorjenke.

${ }^{11}$ Pomenske razlage so večinoma prevzete iz SSKJ, v primerih, kadar bodisi besede ali njihovi pomeni v priročniku niso izpričani, pa so izdelane priložnostno.

${ }^{12} \mathrm{Kljub}$ pogosti rabi obeh je bilo moško poimenovanje $\mathrm{v}$ primerjavi z ženskim parom vendarle večkrat omenjano (coprnik v 15 delih - coprnica v 9 delih; razmerje v DB 1584 pa je npr. coprnik $40 \times$ : coprnica $4 \times)$. 
besedotvornem vzorcu izpeljana delovica ${ }^{13}$ so domnevno lahko zaobsežene osebe moškega in ženskega spola (npr. en Delovez je fvojga lona vrejden (DB 1584: III, 115b)). Na osnovi vrste in značilnosti sobesedilno omenjenih del, ki so jih opravljale osebe, poimenovane kot delavci (npr. v biblijskih prevodih), pa je nasprotno mogoče sklepati, da se je poimenovanje večinoma nanašalo samo na osebe moškega spola, saj bi jih ženske ne mogle, smele ali znale opravljati. Npr.:

Ti imafh tudi veliku Delauceu, Sydarjeu inu Zimèrmanou, h'kamenju inu k'lejffu, inu vfe shlaht modre na vfakèrfhne dellu od slata, frebra, brona inu od shelésa, pres zhifla (DB 1584: I, 230b); TAku fo vfi modri Moshje, mej témi Delauci fturili tu dellu, Prebivalifzhe /.../ Kerubime fo fturili cillu kunfhtnu (DB 1584: I, 59b); Inu je poflal eniga Hlapza /.../ h'tém Delaucem, de bi od téh Delauceu vsel, od fadu tiga Vinograda. Ony fo ga pak vseli, inu fo ga ftepli, inu fo ga puftili prasniga od febe (DB 1584: III, 26a).

$\mathrm{V}$ isto skupino bi bilo po pomenskem kriteriju mogoče uvrščati tudi dobro znane in uveljavljene domače pare: pevec - pevkalpevkinja ${ }_{1}^{14}$ prešušnik/ prešuštnik (tudi presuštnik, prešušnik, prešustnik) z ženskimi pari, prijatelj - prijateljica, služabnik - služabnica, sovražnik - sovražnica, pa tudi prerok - prerokinja, varih - varišica ter varuh - varušica itd. Pri vseh je pogosteje rabljen moški člen, pogostost uresničevanja dejanj in stanj, ki jih izražajo glagoli kot sovražiti, pa tudi služiti, peti in drugi, pa je imela za posledico ne le izoblikovanost poimenovanj za vršilce dejanj ali nosilce stanj obeh spolov, ampak tudi večkratno rabo ženskega člena. $\mathrm{V}$ isti okvir sodi tudi par prikupavec 'ein frawen wirt, oder Hurenwirt' - prikupavica 'hurenwirtin' (MTh 1603 (1977): 151), ki pa se za razliko od prej naštetih zunaj MTh 1603 ne pojavlja. V skupino sodi tudi več parnih poimenovanj s prevzeto podstavo: npr. klafar - klafarica, merdrar - merdrarica, tudi mordar/mordrar - mordarica, martrnik - martrnica itd.

1.1.2.1 Med najbolj znane pare se uvrščata pomensko razširjeni poimenovanji kurbar (tudi kurber in kurbir) in kurba, ${ }^{15} \mathrm{ki}$ sta - običajno posamično, le redko skupaj - zelo pogosto rabljeni (npr. S. Paul te Verne zheftu inu oftru opomina inu praui, de oben nezhifti fmerdezhi Curbar oli Curba ne pride v nebeffa (TC 1575: 387)). Tako prevedena kot samostojnejša dela kažejo, da se v nove pare večkrat povezujejo tudi členi iz različnih besedotvorno oblikovanih parov: npr.

${ }^{13}$ Npr.: vdinani inu naieti delouci inu delouice (TC 1575: 361). Par kot zgled uveljavljenega tvorbenega modela (poleg para, kjer je ženski člen izpeljan z obrazilom -inja: prerokprerokinja) navaja tudi Novak (2001: 115), ki hkrati omenja, da je bila tudi tvorba imen za ženske osebe živahno področje besedotvornega delovanja.

${ }^{14}$ Pogosteje rabljena je bila pevkinja (v DB 1584 se pojavlja 6×; npr. Ieft fim fi tudi dobil Peuce inu Peukine (DB 1584: I, 328b)), danes uveljavljeno poimenovanje pevka, ki ga je Dalmatin uporabil v svojem prvem delu (DJ 1575), izpostavila pa tudi Bohoričeva slovnica, za pevkinjo številčno zaostaja (skupno 2 primera).

${ }^{15}$ V DB 1584 se npr. kurba pojavlja $56 \times$, kurbar pa $18 \times$, v TPo 1595 pa je številčno razmerje pojavitev ženskega in moškega člena para $15 \times: 10 \times$. 
Tu ferze je ena Kurba, ta falfh Vera je en loter (TPo 1595: II,253) - Das hertz ift ein hur / der falfche glaube ift ein bub (TPo 1595: II, CLb). Preko tujih prevodnih ustreznic je potrjena tudi pomenska povezava poimenovanj dinaricapular: ${ }^{16}$ Béshi Dinnarizo, de nepadefh v'nje Shtrike (DB 1584: II, 157) - Fleuch die Bulerin / das du nicht in jre stricke fallest (LB 1545: 1764) - Ne približuj se lahkoživki (SP 1997: 1374). Poimenovanji hkrati širita izbor poimenovanj za osebe, ki se vključujejo v prostitucijo. Mednje poleg že navedenih (npr. prikupavec - prikupavica) spadata še para loter - lotrica, rufijan - rofijanka 'zvodnik - zvodnica'. Npr.: Oli ta Sludi no napela vmei hude nezhifte lotre inu htim Roffiankom, de ob nee zhaft prido (TC 1575: 148).

1.1.3 Več parov sestavljajo tudi poimenovanja moškega in ženskega spola, ki jih označujejo tipične lastnosti ali stanja: npr. grešnik - grešnica,${ }^{17}$ norec norica ${ }^{18}$ neverni/nevernik - nevernica; doktor/doktar in doktorca. ${ }^{19}$ Za vse tri našteta ženska poimenovanja je $\mathrm{v}$ primerjavi s parnimi moškimi značilno zelo redko pojavljanje. Na široko in pogosto rabo samostalnika norec $\mathrm{v}$ primerjavi z redkeje uporabljeno norico npr. zgovorno kaže tudi številčno razmerje v DB 1584: norec se pojavlja $177 \times$, norica pa samo dvakrat. ${ }^{20} \mathrm{Za}$ oba člena zadnjega para sta praviloma značilna znanje in modrost. V TPo 1595 enkrat samkrat ekspresivno (z manjšalnim pomenom) uporabljeni doktorčič pa ostaja brez ženskega para.

Moške in ženske člene parov, izpeljanih iz iste pridevniške podstave, lahko nadomeščajo sopomensko rabljene zveze pridevnikov in samostalnikov. ${ }^{21} \mathrm{Sa}-$ mostalniški deli prilastkovnih zvez poimenujejo moško ali žensko osebo, ki je nosilka lastnosti, izražene s pridevnikom. Npr. Sakaj Jerdit zhlovik vushge

${ }^{16}$ Npr. pular -ja m, amator, Carinth. pular, (<Buhler), Liebhaber, Buler (MTh 1603 (1977): 156).

${ }^{17}$ Bajec (1950: 86) navaja, da je pripona -nik nastala iz - $b n+i k b$ (npr. grešnik iz grêšbn $+i k b$, kar ga uvršča med izpridevniške tvorjenke). Prim. tudi Vidovič Muha 1986: 356. Omenja pogostost obrazila $-i k$, ki se razvršča na besedotvorno podstavo iz vrstnega pridevnika. V DB 1584 sta grešnik in grešnica v razmerju $150: 3$.

${ }^{18}$ Npr.: Norci ferrahtujo modroft inu navuk (DB 1584: I, 317a) - SKusi modre Shene fe hifha gori zimpra: ena noriza pak jo doli dere s'fvoim djanjem (DB 1584: I, 321b).

19 Žensko poimenovanje se nanaša na Jezusovo mater Marijo: ona ta velika Doctorza inu Prerokynja, katera ie vuzheneifha, kakor vfi Apoftoli inu Preroki, te lube Elizabethe peiftinja inu Kluzhariza poftane (TPo 1595: III, 133) - das fie / die groß Doctorin vnd Prophetin / die gelerter ift / denn alle Apoftel vnd Propheten / der lieben Elifabeth kindermagd vnd Kellerin wird (LH 1566: III, LXXVIII). Ženska poimenovanja, nanizana $\mathrm{v}$ zgledu, izkazujejo tvorbo $\mathrm{z}$ obema najproduktivnejšima obraziloma: -inja in -(i)ca; različica $-c a$ je nastala $\mathrm{z}$ redukcijo nenaglašenega $i$-ja.

${ }^{20}$ Podobno številčno razmerje v DB 1584 izkazujejo tudi poimenovanja neverni/nevernik ter neverna/nevernica, ki se drugje ne pojavljata: $154 \times: 149 \times: 1 \times: 1 \times$.

${ }^{21} \mathrm{O}$ soobstajanju in izmenljivosti besedotvorno različnih, hkrati pa sopomenskih poimenovanj (npr. bolni - bolnik, grešni-grešnik) v delih slovenskih protestantskih piscev 16. stol. prim. Legan - Ravnikar 2007: zlasti 109-110 in 113-114. Na sopomensko razmerje med besednozveznimi poimenovanji tipa bolan človek in enobesednimi tvorjenkami (npr. bolnik) v DB 1584 je opozorila J. Narat - Šrekl 1991: zlasti 65-66. 
kreg, inu Neverni zhlovik dobre priatele smoti (DB 1584: II, 164a) - Denn ein zorniger Mensch zündet hadder an / vnd der Gottlose verwirret gute Freunde (LB 1545: 1791).

1.1.4 Med parnimi izsamostalniškimi tvorjenkami so tudi take, ki označujejo pripadnike in pripadnice različnih skupnosti: npr. purgar - purgarica. ${ }^{22}$ Vzporedno omembo obeh členov v TPo 1595 je spodbudila Lutrova prevodna predloga:

Per tem my ne hozmo, aku Bug hozhe, biti, Temuz /.../ hude purgarje inu purgarize tukaj puftiti, kateri /.../ ta Evangelium preganjajo /.../ tijfti bodo tukaj morali plazhati (TPo 1595: I, 10) - Da wöllen wir / ob Gott wil / nit bey fein / fonder /... / böfe Burger vĩ Bürgerin da laffen / die jetzt /.../ das Euangelion verfolgen /.../ diefelbigen werden da bezalen müffen (LH 1566: I, VII).

1.1.5 Med značilna besedotvorna razmerja se uvrščajo tudi pari samostalniške rabe pridevnika moškega spola in ženska obrazilna tvorjenka: npr. hudobni/ hudobnik in hudobnica, ${ }^{23}$ ki se parno ne moreta povezovati, saj ju razdvaja izkazani pomen samostalnika ženskega spola 'mrzlica'.

1.1.6 V cerkveni hierarhiji je moških poimenovanj, ki bi potrebovala vzporedno izpeljavo ženskega para, malo. Poleg osnovnega poimenovalnega para menih - nuna, s katerim sta označena pripadnika moškega in ženskega samostanskega reda, obstajajo še pari priol - priolovka oz. prior - priorivica ${ }^{24}$ ter apat (tudi abat, apt in opat) - abačica (tudi abtašica), ki s poimenovanjem predstojnikov posredno kažejo na obstoj različnih (moških in ženskih) samostanskih redov. Npr.

Ampak de bi te Menishke inu Nunske Oblube, kir oblubio pres Mosh oli pres Shen shiueti do Jmerti, Vbushtui prebiuati, Inu nih Appatu, Priolu, oli Abbazhici oli Prioriuici pokorni biti, Ena taka della inu take velike Boshye Slushbe bile, De fo bulshe, inu fueteishe koker ty drugi Stanuui (TAr 1562: 81b).

${ }^{22}$ Purgarica se kot par splošno razširjenega purgarja pojavlja samo v TPo 1595, kjer sta v razmerju $1 \times: 55 \times$.

${ }^{23}$ Protestantski pisci so najraje segali po posamostaljeni obliki pridevnika hudoben: hudob$n i$, ki se pogosto protipomensko povezuje s pravičnim (npr. Kadar pravizhni premagajo, taku cillu lipu gre: Kadar pak hudobni gori prideo, fe morajo ludje Jkrivati (DB 1584: I, 327a)), tvorjenko hudobnik je brez neposrednega Lutrovega vpliva enkrat samkrat uporabil Dalmatin v Bibliji (Raunu kakòr de bi ta Hudobnik satu tukaj fedil, de bi on imel tu Kèrfzhanftvu martrati s'Poftavami (DB 1584: II, 89a) - Als sesse er darumb da / das er die Christenheit / mit Gesetze /... / muste zuplagen (LB 1545: 1518). Hudobnica se v pomenu 'mrzlica' pojavlja v obeh Megiserjevih slovarjih: npr. Fieber. (DeutCch.) febris. (Latinè.) Cr. febra, simniza. mersliza, hudobniza, treshlika. (Windifch.) febre. (Italicè.) (MD 1592: D7).

${ }^{24}$ Vsa štiri navedena poimenovanja so znana iz Trubarjevega jezika, od koder je tudi par apat - abačica, različico abtašica pa navaja Megiser v slovarju iz leta 1603: abtašica -e ž, antiftita, abtafhiza, Priorin oder Aptissin (MTh 1603 (1977): 3). 
Izmenična raba različic priorivica $(1 \times)$ in priolovka $(1 \times)$ kaže, da najprimernejši tvorbeni način ženskih poimenovanj še ni bil izbran. K variantnosti prispeva tudi neodločenost glede izbire moškega člena (v TAr 1562 je dvakrat izpričan priol, v TPo 1595 pa enkrat prior).

Rabo para bog - boginja omogoča mnogoboštvo, kar jasno kažejo tudi biblijski prevodi: npr. tu Meftu Ephesus Slushi tej veliki Bogini Diani (DB 1584: III, 72b). Želja, postati podoben Bogu, je bila odločilna pri ravnanju prve ženske - Eve, vplivala pa je tudi na uporabo poimenovanja samostalnika boginja $\mathrm{v}$ nekoliko spremenjenem pomenu (kot ženskega para edinemu znanemu (krščanskemu) bogu):

Sakai kakor ie Hudizh Euy /.../ obliubil, ako od Sadu prepouedaniga Driuefa iedla bude, tako bude Boginia, ter io ie tako ftem sapelial (JPo 1578: III, 57b (prav 107b)) - Denn wie der Teuffel Eua /.../ verhey/t /.../ wo fie von der verboten Frucht effe / folt fie ein Göttin werden / verfürte fie alfo damit (SA 1566: III, LXXXVII).

Iz nemščine prevzeti samostalnik far, ki je $\mathrm{v}$ delih slovenskih protestantskih piscev 16. stoletja nevtralno rabljen $\mathrm{v}$ pomenu 'duhovnik', ${ }^{25}$ spremlja dvakrat navedeni (enkrat v TR 1558, drugič pa v predgovornem besedilnem okolju v TT 1577) ženski par farica, ki je v TR 1558 zanesljivo rabljena v pomenu 'žena farja/duhovnika': »Zaharias S. Iansha Ozha ie bil en Far, Elizabeta nega Mati ie bila ena Faryza, fta V fakonu vkupe veliku leit prebiuala /.../ inu slushila prou Bogu« (TR 1558: e2b). ${ }^{26}$

Žensko poimenovanje spremlja tudi izrazito prevladujočega predigarja. V DB 1584, kjer se pojavlja predigarica, je medsebojno razmerje $94 \times: 2 \times$. Predigarica se obakrat (v dveh zaporednih povedih) pojavlja v označevalni vlogi: »lerusalem ti Predigariza, povsdigni tvojo fhtimo (DB 1584: II, 16a) Jerusalem du Predigerin heb deine stim auff« (LB 1545: 1229).

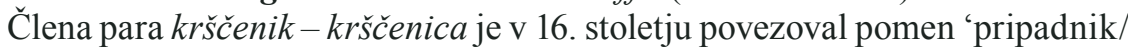
pripadnica krščanske vere': npr. »Criftiani ali Karfzheniki fo imenovani vfi Verni (DB 1584: I,)(IIIb); Sakai ta beffeda, Ieft fem ena Kerfzheniza fapopade ufe Articule, kir hti Kerfzhanfki Veri flishio« (TO 1564: 160b).

\subsection{Parna poimenovanja sorodstvenih in drugih razmerij}

1.2.1 Temeljni člen sorodniških razmerij predstavlja poimenovalni par oča - mati. Poimenovanji sta običajno rabljeni v prvem pomenu: oča $\mathrm{v}$ pomenu 'moški v odnosu do svojega otroka', mati pa v pomenu 'ženska v odnosu do svojega otroka'. Samostalnika sta primerljivo pogosta. Npr. Sakaj ona nej imela ni Ozheta ni Matere (DB 1584: I, 236a, pravilno 263a). Opazna posebnost je

${ }^{25} \mathrm{Npr}$. VTim zhaffu tiga Erodesha Krala te Iudouske deshele, ie bil en Far, od te Abiaue zhrede, timu ie bilu Ime Zaharias, nega shena ie bila /.../ Elizabeta (TT 1581-82: 217).

${ }^{26} \mathrm{O}$ duhovniški službi v stari in novi zavezi in o Zahariji kot duhovniku prim. Biblični leksikon, 1984: 258, 778. 
narečno izpričana poimenovalna variantnost moškega člena razmerja, saj očeta spremljata še atej $^{27}$ in atel, poimenovanje mati pa ostaja brez različic. Drugi par sorodstvene verige predstavljata korensko različni poimenovanji $\sin$ in $h c ̌ i ~(n p r$. on nej ficer obeniga Synu ni Hzher imèl (DB 1584: I, 140a). Hči v Trubarjevem jeziku obstaja tudi v glasoslovni različici šči (npr. Syn, Szhi (TC 1575: 304)), v ZK 1595 pa se ji pridružuje še besedotvorna različica hčerka (Inu je taku ta lubi Ozhaniz fvoje nar vekfhi ve/seljé imèl nad tem, kir je njegova Hzherka nekotere lepe Shpruche /.../ svunaj snala povedat (ZK 1595: 40)). ${ }^{28}$ Parno razmerje se ohranja tudi na nivoju manjšalnic (sinek in sinko - varianti so uporabljali zlasti Trubar, Krelj in Juričič, ter hčerčica, znana iz Trubarjevega novozaveznega prevoda in iz DB 1584: npr. Sakaj ena Shena je od njega flifhala, katere Hzherzhiza je iméla eniga nezhiftiga Duha (DB 1584: III, 23a)). Stare starše poimenuje par z dvočlenskim, sopomenskim moškim izhodiščem: ded/dedec - baba. Npr. Moj Dejdez, Iesus (DB 1584: II, 153b); ${ }^{29}$ Nahor, Abrahamou Ded (DB 1584: I,)((1)IVb) - inu ieft fmishlauam na to tuio Vero, kir ie pres hynena vtebi, katera ie poprei prebiuala vtui Babi Loidi, inu vtui Materi Euniki, inu ieft fem faguishan de tudi vtebi (TL 1567, 69b). ${ }^{30}$ Med splošno uveljavljenima sopomenkama ded in dedec je bil zadnji po številu rab celo na prvem mestu. Obe sta navedeni tudi v Megiserjevih slovarjih, ki prinašata parna poimenovanja še bolj oddaljenih sorodstvenih stopenj: preded in prebaba ter prevnuk in prevnuka. Iz tujih ekvivalentov za člena zadnjega para je razvidno, da gre pri prevnuku dejansko za moškega potomca in ne morda za spolsko nevtralno poimenovanje (npr. Kindskindsfohn. (Deut Cch.) pronepos. (Latinè.) prevnuk, (Windifch.) figlivolo di mio nepote per dritta linea (Italicè.) (MD 1592: H2b)).

Sorodstveno strukturo izrisujejo še naslednja parna poimenovanja: Brat sestra; samostalnika sta uporabljena $\mathrm{v}$ osnovnem in $\mathrm{v}$ drugotnih pomenih (npr. Obtu vi mui lubi Bratie inu Seftre (TC 1575: 415), ${ }^{31}$ kjer gre za aktualizacijo pomena 'kdor je komu soroden po mišljenju ali usodi'). Stric - teta: Mui dobri

${ }^{27}$ Oblika je s pripisano oznako Carinth. navedena v MTh 1603 (1977): 5. Različico atel je uporabljal Trubar: npr. Abba, Pater, Tu ie, Lubi Atel, lubi Ozha (TR 1558: N4a). Na nenevtralnost poimenovanja posredno kaže sopojavljanje značilnega prilastka (muj ali lubi), s katerim je posebej poudarjeno bodisi sorodstveno razmerje govorečega ali njegova čustvena navezanost na roditelja.

${ }^{28}$ Navedeni zgled izkazuje tudi tvorbeno različico očeta: očanec, ki mu na osnovi sobesedila ni mogoče pripisati jasno izražene pomenskorazločevalne lastnosti. Prim. tudi: Gdu ie omiflil inu shivil tiga Ozhanca Iakopa kateri ie ob palici zhes Iordan Jhal, inu ie nasai pèrfhal s'veliko mnoshico (KPo 1567: LXIXb) - Wer ernehrte den Ertzuatter Iacob / da er am ftab vber den Iordan gieng vnnd kam wider mit groffem volck (SA 1559: I, LIIIb). Predvidevati je mogoče, da ga označujejo lastnosti (npr. spoštovanje pravih vrednot, starost in častitljivost), ki so ob drugem še danes sestavine njegovega pomena.

${ }^{29}$ Prim. MEin Grosvater Jesus (LB 1545: 1752).

${ }^{30}$ Prim. slovarski sestavek baba - Novak v Merše, Novak, Premk 2001: 44-45.

${ }^{31}$ Prim. slovarski sestavek brat - Novak v Merše, Novak, Premk 2001: 48-50. 
poshteni Sofid, Striz, Boter oli periatel (TC 1575: 223);32 teta (tetta, Mutterschwester, Vaterschwester /.../) (MD 1592 (1967): 141); Inu pole, Elisabet tvoja Teta, je tudi no/sezha eniga Synu (DB 1584: III, 30a) - Vnd sihe / Elisabet deine gefreundete / ist auch schwanger mit einem Son (LB 1545: 2071); NIhzhe fe néma k'fvoji blishni Teti pèrdrushiti (DB 1584: I, 71b) - NJemand sol sich zu seiner nehesten Blutfreundin thun (LB 1545: 234). Zadnja dva zgleda kažeta, da je teta $\mathrm{v}$ protestantskih biblijskih prevodih večkrat nadomeščala Lutrovo splošnejše poimenovanje za krvno sorodnico. ${ }^{33}$ Pojavljanje poimenovanja strina v pomenu 'stričeva žena' (npr. Ti némafh tvojga Ozheta Brata fram odgèrniti, de bi njega sheno vsel. Sakaj ona je tvoja Strina (DB 1584: I, 72a) - DV solt deines Vaters bruder shamd nicht blössen / das du sein Weib nemest / denn sie ist deine Wase (LB 1545: 235)), ${ }^{34}$ ki je etimološko (Bezlaj 1995: 328-329) in pomensko tesno povezano s stricem, odpira možnost manj aktualne parne kombinacije, v katero bi bil prav tako včlenjen stric. Slovarsko zabeležena so tudi poimenovanja naslednjega sorodstvenega kroga: tetič 'der Sohn der Tante' - tetična 'die Tochter der Tante' (v MD 1592), ter strinič 'Vattersbruderskind', ki je (enkrat) naveden tudi v DB 1584 kot enobesedna sopomenka besednozveznega poimenovanja: ga more eden njegovih Bratou réfhiti, ali njegou Striz, ali *ftrizheu fyn *Strinizh [robna opomba] (DB 1584: I, 76b)). Splošno uveljavljen je bil poimenovalni par tast - tašča. Na poudarjeno vlogo ženskega člena para kaže obstoj različno uveljavljenih sopomenk: polnica in svekrv. Obe poimenovanji navajata Megiserjeva slovarja, polnico pa je uporabljal tudi Trubar.

Kot ženski par sopomenskih poimenovanj svak in dever (pisno diver) - prvi je pogosteje rabljen kot drugi - bi bilo predvsem na osnovi sobesedilne rabe in sočasne slovarske registracije mogoče upoštevati večpomensko nevesto (Schägerin. (Deut Tch.) fratria. (Latinè.) nevefta. (Windifch.) moglie del fratello (Italicè.) (MD 1592: N7a); Hzhy fe ftavi supèr Mater, *Snaha je supér Tafzho *Nevéfta [robna opomba] (DB 1584: II, 118b), ${ }^{35}$ ki je sicer ustaljeni ženski par samostalnika ženin, v pomenu 'svakinja' pa par svaka. Zunaj sorodstvene strukture, čeprav še vedno blizu nje, se umešča par očim - mačoha. Njegova

32 Vsi samostalniki moškega spola, našteti v zgledu, imajo kot poimenovanja najosnovnejših sorodstvenih in medčloveških razmerij ob sebi tudi ženske pare (npr. sosed + soseda, stric + teta, boter + botra, prijatelj + prijateljica), ki so sicer prav tako splošno uveljavljeni, vendar redkeje rabljeni od moških členov para.

${ }^{33}$ V slovarju, ki je dodan izdaji LB 1545 v DTV (1974) in ki zajema zastarelo, manj znano in težko razumljivo Lutrovo besedje, je samostalnik blutfrud(in) pojasnjen kot '(Bluts-) Vervandter' (LB 1545 (1974): 311*.

${ }^{34}$ V LB 1545 uporabljeni samostalnik wase je razložen kot 'tante' (LB 1545 (1974): 388*). Ustreznica teta je uporabljena tudi v SP 1966, kjer je navedeno mesto prevedeno takole: Ne odkrivaj nagote brata svojega očeta; ne bližaj se njegovi ženi; tvoja teta je! (SP 1996: 170).

${ }^{35}$ Orožen (1996: 212-213) posebej obravnava kranjsko-slovenske ali bezjačke kontaktne sinonime (tudi nevesto), ki so postopoma (preko robnih navedb) postajali del Dalmatinovega knjižnega jezika. 
člena opredeljuje enako razmerje do tretje osebe - otroka zakonskega partnerja, ki se slovarsko tudi pojavlja $\mathrm{v}$ obeh spolskih različicah: pasterek-pasterkinja.

Našteti pari kažejo, da je pri sorodstvenih poimenovanjih pogosto izpričana nadomestna osnova: npr. oča - mati, sin - hči itd.

Na sorodstveno verigo je mestoma pokazano le z izbranimi členi. Pričenja jo bodisi njen izhodiščni člen ali poimenovanje, ki označuje najbližjega sorodnika osebe, o kateri se govori. Npr.: »inu bo fturil, kar nefo njegovi Ozheti inu Dejdi mogli fturiti (DB 1584: II, 102b); De en Ozha Jam ne ima fuiga Synu, do Jmerti byti« (TC 1575: 353).

1.2.2 Biološko različnost človeka v različnih življenjskih obdobjih poimenujejo pari mož - žena (npr. kadar je Bug Zhlovéka bil ftvaril, po podobi Boshji /.../ Mosha inu Sheno je on nje ftvaril (DB 1584: I, 4a) - Da Gott den Menschen schuff / machet er jn nach dem gleichnis Gottes / Vnd schuff sie ein Menlin vnd Frewlin (LB 1545: 2)); ${ }^{36}$ hlapčič - deklica, tudi hlapčič in dečla, ${ }^{37} \mathrm{kjer}$ je pri moškem členu razmerja $\mathrm{z}$ obrazilom -čič domnevno aktualiziran le pomen mladosti, ne pa tudi majhnosti (npr.: Tu je ta Poftava, sa to, katera eniga Hlapzhizha, ali Déklizo rodi (DB 1584: I, 68a); inu fe néfo fhonali, ni Hlapzhizheu ni Dézhel, ni Stariga ni Dedzou (DB 1584: I, 250b) - vnd verschonete weder der Jünglinge noch Jungfrawen / weder des Alten noch der Grosveter (LB 1545: 854); Sakaj kakòr en Hlapzhizh lubi eno Dezhlo, taku bodo tebe tvoji otroci sa lubu iméli (DB 1584: II, 24b)).

Mož v Bibliji (in v drugje navedenih biblijskih odlomkih) nastopa tudi v paru z istokorenskim samostalnikom ženskega spola možica: »Inu Adam je djal: Letu

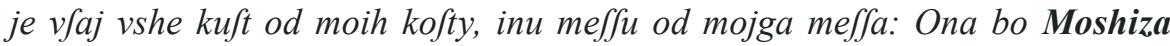
imenovana, satu, ker je is Mosha vseta« (DB 1584: 1585: I, 2b).

Ob splošno razširjeni možici se v TC 1550 pojavlja še različica možiča (ona bode Mofhyzha imenouana (TC 1550 (6a)). Na dejstvo, da je Bog ustvaril prvo žensko iz moške kosti, je pokazano tudi z besedno tvorbo, saj je možica izpeljana iz samostalnika mož s specializiranim obrazilom -ica. ${ }^{38}$

Sobesedilne rabe samostalnikov ženskega spola kažejo na raznosmerne pomenske širitve: deklica je uporabljena tudi v pomenih 'dekle' in 'devica' (npr. ta Dézhla nej dékliza najdena /.../ Satu ker je ona eno noroft v'Israeli fturila, de fe je v'vojga ozheta hifhi kurbala (DB 1584: 111b) - das die Dirne nicht ist jungfraw finden (LB 1545: I, 176)).

1.2.3 S pari kot npr. boter - botra, sosed - soseda pa so parno zaobsežena tudi druga medčloveška razmerja. Npr.:

\footnotetext{
${ }^{36}$ Par se običajno uporablja za označevanje zakonskih partnerjev (npr. TEm pak kir fo v'Sakoni, sapovém /.../ de fe Shena nelozhi od Moshá (DB 1584: III, 91b)).

${ }^{37}$ Dečla je pogosto rabljena v enem izmed dveh osnovnih pomenov: 'dorasla mlada ženska, ki še ni poročena' in 'doraščajoča oseba ženskega spola'. Npr.: Sakaj takove Suknje fo Krajleve Hzhere no/sile, dokler fo Dezhle bile (DB 1584: I, 174b).

${ }^{38} \mathrm{~V}$ sodobnem biblijskem prevodu (1996) je tvorba tekla v smeri mož + inja $\rightarrow$ možinja (Tedaj je človek rekel: "To je končno kost iz mojih kosti in meso iz mojega mesa; ta se bo imenovala móžinja, kajti ta je vzeta iz moža." (SP 1996: 54-55).
} 
Vi Botri inu Botre, vi imate veiditi fa kai inu fa zhes volo fte vi od tih Starisheu letiga Diteta, kletimu Kerszhouanu naprosheni inu pouableni (TC 1575: 425); Taku govori vshe sdaj pred tém Folkom, de profsi Jlejdni od fvojga SoJséda, inu Jlejdna od fvoje Sosséde freberne inu slate Poffode (DB 1584: I, 4lb).

Dokazilni zgled za obstoj para sosed - soseda kaže, da se hotenemu začetnemu razlikovanju med osebami moškega in ženskega spola prilagajajo tudi nadaljnje omembe oseb. $\mathrm{Z}$ moškim poimenovanjem sosed, zlasti z njegovimi množinskimi oblikami (npr. sosedi/sosedje), pa so praviloma mišljene osebe moškega in ženskega spola: TRy lépe rizhy fo /.../ Myr mej bratmi, lubesan mej Joffedmi, inu kadar fe Mosh tèr Shena dobru mej fabo glihata (DB 1584: II, 163a).

Pogostnostno razmerje, ki ga kažejo rabe členov para vdovec - vdova, je zgovorno: zaradi socialne ogroženosti, ki je nastopila po moževi smrti, je bila (predvsem v biblijskih besedilih) ${ }^{39}$ zelo pogosto omenjana vdova (v DB 1584 $128 \times$ ), vdovec pa le $\mathrm{v}$ treh delih: $\mathrm{v}$ dveh Trubarjevih (po ena omemba $\mathrm{v}$ TAr 1562 in v TC 1575) in v TkM 1579 (dve omembi); vse štiri omembe so del para: npr. MOLITOV ENIGA Vdouza inu ene Vduue (TkM 1579: 109b); Ieft fim ena Vduva, ena Shena kir trouram, inu moj Mosh je vmèrl (DB 1584: I, 175a). Zgled OBeno Vduvo ali Siroto nereshalite (DB 1584: I, 49a) opozarja, da so šibkejši in bolj ranljivi plasti človeške družbe pripadale tudi sirote. Samostalnik sirota je kljub ženskemu spolu lahko uporabljen kot spolsko nevtralno poimenovanje za otroka brez staršev. My fmo Syrote, inu nemamo Ozheta, nafhe Matere fo kakòr Vduve (DB 1584: II, 57b).

Ena izmed orientalnih značilnosti, predstavljenih v Bibliji, je bilo tudi mnogoženstvo, ki se je poimenovalno odražalo v enosmerni tvorbi poimenovanj:

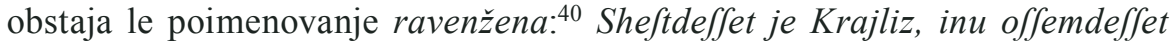
ravenshen, inu Dézhel nej zhifla (DB 1584: I, 111b).

Od pravila, da so parna poimenovanja samostalniki moškega in ženskega spola, odstopa splošno rabljeni samostalnik druže, ki je srednjega spola, nanaša pa se lahko na osebe moškega ali ženskega spola. Parno žensko poimenovanje izhodiščnega moškega člena drug, ki je naveden kot kranjska iztočnica v Registru DB 1584 (Drug [Crajnfki.] Továrifh [Hervazki, Dalmatinfki, Iftrianfki, Crafhki.] (DB 1584: III,CcIVa)), je družica, ki je uporabljena v biblijskih prevodih: npr. ker je ona vfaj tvoje drushe, inu Shena tvoje Savese (DB 1584: II, 131a).

${ }^{39}$ Npr.: Inu Praudo ftury Sorotam, inu Vduvam, inu ima ptuje sa lubu, kir nym Jhpisho ino gvant daje (DB 1584: I, 106b). Isto mesto (ki pomaga do pravice siroti in vdovi, ljubi tujca in mu daje kruha in obleke) je v sodobnem slovenskem biblijskem prevodu pojasnjeno z opombo: »to so tri najšibkejše skupine v starozavezni družbi. Ker so sicer brez varstva, imajo pravico, da zanje skrbita Izraelov Bog in njegovo ljudstvo« (SP 1996: 240).

${ }^{40}$ Sklopa ravenmož ni, obstajajo pa številne druge tovrstne tvorjenke: ravenbrat, ravenčlovek, ravenhlapec itd. 
1.2.4 Redka parna poimenovanja so ugotovljiva tudi pri pripadnikih različnih skupin in skupnosti (npr. verskih): npr. ajd - ajdinja/ajdenja (glasoslovna variantnost, ki je posledica izgovornega slabljenja nenaglašenega i-ja, je Trubarjeva značilnost) ${ }^{41}$ Čeprav sta bili obe poimenovanji splošno razširjeni, je moški člen občutno prevladoval (v DB 1584 sta ob večstokratnem pojavljanju samostalnika ajd izpričani samo dve pojavitvi ajdinje).

1.3 Parna živalska poimenovanja, tvorjena z obrazilno izpeljavo, so poleg najsplošnejšega para samec - samica, nanašajočega se na živali (npr. Vsami k'febi od vfake zhifte Shivine, vfelej fedem inu fedem, eniga Jamza inu njegovo Jamizo (DB 1584: I, 5a)), še: golob-golobica, hrt-hrtica, ${ }^{42}$ junec - junica (razmerje je omejeno le na spolno različnost poimenovanih živali) ${ }^{43} \mathrm{kozel}^{44}$ - koza, osel - oslica, pes - psica ${ }^{45}$ prašičlprešič - prasicalpresica, volk - volčica, vran - vrana, lav/lev, ki ga spremljata dve ženski poimenovanji: lavíca in levinja. Prva je slovarsko navajana različica, druga, izpeljana $\mathrm{z}$ redkeje uporabljanim obrazilom -inja, pa je bila sobesedilno rabljena v Dalmatinovih biblijskih prevodih. Korensko različne pare oblikujejo poimenovanja jelen - košuta, ${ }^{46}$ oven in jarec ter ovca, petelin - kokoš. Ob kokoši se občasno pojavlja kokalnica, ${ }^{47}$ ki jo pomensko označuje in osamosvaja valjenje in vodenje piščancev. V tem

${ }^{41} \mathrm{Npr}$. ona tiga Shtuka posabi, inu is mifli pufti, de je ona ena Ajdina, on pak je en Iud (TPo 1595: I, 161). Nasprotje, ki ga oblikujeta ajdina in Jud, je spolsko in vsebinsko: pripadnica vere, ki ne priznava Kristusa, in pripadnik judovske vere.

${ }^{42} \mathrm{Na}$ neizenačenost rabe členov para kaže poleg redkejšega pojavljanja hrtice tudi njena samo slovarska navedba: npr. Windfpil. (Deutfch.) canis venaticus. (Latinè.) hèrtiza, lovèn pèß. (Windifch.) levriero, veltro (Italicè.) (MD 1592: V5). Rabe uzaveščajo predvsem obstoj pasje pasme in ne toliko potrebe po poimenovalnem razločevanju moškega in ženskega para, na kar kaže hrtici pripisana razlagalna sopomenska zveza lovèn pèß

${ }^{43}$ Pogostnostno razmerje je bilo preverjeno v DB 1584: ugotovljenih je bilo 100 pojavitev junca in šest junice.

${ }^{44}$ Brez ženskega para ostajata obe manjšalnici: splošno razširjena kozlič in iz Megiserjevega slovarja znani kozlec.

${ }^{45}$ Parnost sega tudi na območje manjšalnic, kjer sta iz pojavitev v besedilih različnih piscev sestavljiva kar dva različno tvorjena para: psič - psičica in psiček - psička. V prvem primeru gre za izpeljavo ženskega člena para z obrazilom -ica, v drugem pa za zamenjavo obrazil: oba člena para sta drugostopenjski tvorjenki, izpeljani s tipičnima manjšalnostnima obraziloma (-ek: $-k a)$.

${ }^{46} \mathrm{~V}$ biblijskih prevodih se pogosto parno pojavljata srna in jelen, vendar primerjava s prevodno predlogo in sodobnim biblijskim prevodom kaže, da gre za poimenovanji različnih živali in ne za člena istega para: Od tiga mogo zhifti inu nezhifti jéfti, kakòr eno Sèrno ali eniga Ielena (DB 1584: I, 107b) - Beide der Reine vnd der Vnreine mügens essen / wie ein Rehe oder Hirrs (LB 1545: 359); Nečisti in čisti ga sme jesti kakor gazelo in jelena (SP 1996: 243).

${ }^{47}$ Npr.: kakòr ena Kokalniza zhes Iajza peruti refproftira, je greje inu leshe (DB 1584: I, 1a). Slednja je glede na značilna opravila ali lastnosti tudi v slovenskem okolju dobila več posebnih poimenovanj: kokalnica, narečno tudi kvokarha (v tretjem registrskem stolpcu DB 1584: Sloven $k$ ki, Besjazhki) Reg. 3) in kvočka (v četrtem registrskem stolpcu). Večino poimenovanj je motiviralo značilno oglašanje domače ptice. 
pomenskem okviru parno povezovanje s petelinom ne more biti vzpostavljeno. Istokorenski par sestavljata kur 'petelin' in kura, toda o temeljni sopomenskosti tudi pri njima ni mogoče govoriti, saj se kura, ki je znana predvsem iz obeh Megiserjevih slovarjev, v zvezi z divji pojavlja kot poimenovanje za fazana ali celo divjega petelina (npr. Fafan. (Deutfch.) phafianus. (Latinè.) fafan, divje kure. (Windifch.) fagiano. (Italicè.) (MD 1592: D5)). Pri številnih živalskih poimenovanjih je opazno metaforično širjenje pomena; npr. Ali ena je moja Golobiza, moja brumna, ena je fvoji Materi nar lublifha (DB 1584: I, 333b). V Bohoričevi slovnici je naveden par konj - konjka, na osnovi ločenih pojavitev konja in kobile pa je sestavljiv tudi ta par: konj je splošno razširjeno poimenovanje, kobilo pa v obeh slovarjih navaja Megiser: npr. kobila-e ž, equa, kobila, kluffina, Stut, Mötsch, Mutterpferdt, Feldin (MTh 1603 (1977): 62). V MTh 1603 jo spremlja sopomensko poimenovanje kljusina, ki sobesedilno nastopa $\mathrm{v}$ paru s pastuhom 'žrebcem':48 Kakòr Paftuh risazhe pruti vfem klufinam, taku fe Hinavez na vee Shpotliuce obéfha (DB 1584: II, 166b). Povezava učinkuje ekspresivno.

Poimenovanji ptič in ptica nastopata v vlogi sopomenk. Samostalnika sta (po enkrat) izpričana samo v BH 1584. Npr.: Ptiza, ze, ptizh, a, auis, vogel (BA 1584. 58); Ptice pod Nebom inu shivina, tu je vfe prozh (DB 1584: II, 32a).

Brez parnega ženskega člena so ostala poimenovanja skopljenih živali, npr. kaštrun, vol.

1.3.1 Za številne omenjene živalske (pa tudi nekatere rastlinske) vrste in družine so bila $\mathrm{v}$ rabi bodisi samo moška ali samo ženska poimenovanja, ki označujejo žival z vsemi njej lastnimi razlikovalnimi potezami, hkrati pa brez opaznejše spolne diferenciacije. V tej vlogi npr. nastopajo naslednja poimenovanja moškega spola: drozg, fazan, jazbec, kit, krt, kuščer, leopard, lobud, medved, pard, pav, pes, pivol, ${ }^{49}$ škorec, škorjanec, škorpijan/škorpijon itd. ter naslednja poimenovanja ženskega spola: afinja ${ }^{50}$ bolha, čaplja, grlica, hijena, jerebica ${ }^{51}$ kamela, kuna, ${ }^{52}$ lastovica, lisicallesica, mačka, štorklja, ob ovci tudi

${ }^{48}$ Prim. PS 1895: II, 13.

${ }^{49}$ Samostalnik se pojavlja v obeh slovarjih in v DB 1584 . Zadošča omemba živalske vrste, potrebe po navedbi poimenovanja samice (v Pleteršnikovem slovarju in v SSKJ je navedena bivolica) pa ni bilo.

${ }^{50}$ Iz nemščine prevzeta beseda je bila splošno razširjena.

${ }^{51}$ Npr. Sakaj Israelfki Krajl je vunkaj fhàl yfkat eno Bolho, kakòr fe ena Ierebiza poja po gorrah (DB 1584: I, 165b).

${ }^{52}$ Korenska izenačenost bi brez sobesedilnega preverjanja lahko usmerjala k napačni povezavi kune in kunina oz. kuniliča ali kunuliča, ki pa se po preverjanju pokaže kot poimenovanje za skalnega jazbeca. V DB 1584 je kinilič v robni opombi predstavno približan s približno sopomenko zajčič: Viffoke Gorre fo divjih Kos prebivalifzhe, Inu Skale téh *Kunilizheu. *Sajzhizheu [robna opomba] (DB 1584: I, 305b). Na različnost poimenovanega predmeta (denotata) kaže tudi primerjava niza Saiz inu *Kunulizh *Sajzhiz [robna opomba] (DB 1584: I, 108a) s prevodno predlogo: der Hase / vnd Caninchen (LB 1545: 362). Trubarjeva praksa je drugačna, kar je verjetno posledica druge prevodne predloge: Te viffoke gorre fo tim dyuym kofom hbeshanu, Inu tu skalouie tim +kunynom 
brav, ki je v Pleteršnikovem slovarju razložen kot brav, m. 1) das Schafvieh (ohne Rücksicht auf Alter und Geschlecht) (PS 1894: I, 52). Npr. Barke /.../ fo pèrnefsle Slata, Srebra, Slonovih kofty, Affinje inu Pave (DB 1584: I, 238b); Sove inu Vranuvi bodo ondi prebivali (DB 1584: II, 13b). Na navedenem mestu iz Biblije so omenjene dragocenosti in živalske vrste, ki so jih trgovske ladje vozile iz daljnih dežel. Enospolna omemba je toliko bolj razumljiva, če gre za enkratno navedbo, ki je hkrati tudi slovarska, kar večinoma pomeni tudi nesobesedilno rabo (npr. Troftel. (Deutfch.) turdus. (Latinè.) drufg. (Windifch.) tirdi. (Italicè.) (MD 1592: Q2b)).

Na različne vrste živali (npr. žuželk, nočnih ptic itd.) in ne na spolno razlikujoče se člene parov kažejo tudi poimenovanja kot čuk in sova, čebela/čmela in čmrlj. Sova in čuk sta v DB 1584 uporabljena tudi v medsebojno pojasnjevalni vlogi, kar odpira možnost sopomenskega razumevanja: Ieft fim raunu kakòr en *Zhuk v'opufzhenih mejftih *Sova (DB 1584: I, 305a). Primerjava s Trubarjem je na istem mestu odkrila manjšalnico moškega spola sovič. V obeh primerih gre za prevodni približek nemški ustreznici Kützlin (Jch bin gleich wie ein Kützlin in den verstöreten Stedten (LB 1545: 1052)), ki tudi označuje vrsto sove.

Nasprotno pa sta poimenovanji papagaj in papiga v KPo 1567, kjer se pojavljata drug ob drugem, uporabljeni sopomensko. Npr.: Ti fo prave Papagoij alli papige inu Kavke, katere pres ûma fe govoriti ûzhe (KPo 1567: V). ${ }^{53}$

Brez moškega para se $\mathrm{v}$ delih slovenskih protestantskih piscev 16. stoletja pojavlja krava, ki se sobesedilno pogosto povezuje z volom oz. voli: npr. Krave inu Volli (TPo 1595: I, 32a).

1.4 $\mathrm{Na}$ izbiro moškega ali ženskega poimenovanja je praviloma vplivala situacija. Če se je pripoved nanašala na skupino, ki so jo sestavljale osebe moškega in ženskega spola, je bilo običajno uporabljeno moško poimenovanje (najpogosteje v množini: npr. inu fo veliku bolnikou s'oljem shalbali, inu fo je osdravili (DB 1584: III, 22a); inu je imèl pet Loup, v'katerih je leshala ena velika mnoshiza bolnikou, flépzou, krulovih, Juhih, ty fo zhakali, kadaj bi fe voda Skalila (DB 1584: III, 49b)), ${ }^{54}$ če pa je beseda tekla o ženski kot vršilki dejanja ali nosilki lastnosti, je bilo uporabljeno žensko poimenovanje. Npr. Ona gre tiakaj /... inu is mifli pufti, de je ona ena Ajdina, on pak je en Iud (TPo 1595: I, 161).

$\mathrm{Z}$ redkimi omembami deželana oz. deželanov so v okviru pomena 'predstavnik deželnih stanov' mišljene osebe moškega spola, $v$ pomenu 'kdor je v razmerju do drugega iz iste dežele' pa bi bile lahko ob moških zajete tudi

+Ieshom oli kunigló [robna opomba] (TPS 1566: 187b). V povzemalni opombi, dodani ob robu besedila, so našteti: Serne, kofe, Saici.

${ }^{53}$ Iz nemščine prevzeti papagaj je bil pogosteje rabljen. V glasoslovno modificirani obliki ga je slovarsko vključil tudi Megiser: npr. Papagey. (Deutfch.) p fittacus. (Latinè.) popagaj. (Windifch.) papagallo. (Italicè.) (MD 1592: L2b).

${ }^{54} \mathrm{Na}$ izbiro moških poimenovanj je vplivala tudi splošna uveljavljenost le-teh. Ker se npr. samostalnik bolnica kot ženski par bolnika v knjižnem jeziku 16. stoletja še ni pojavil, je bila izbira moškega para tudi v primeru hkratne nanašalnosti na ženske logična. 
osebe ženskega spola (prim. slovarski sestavek deželan - Novak v Merše, Novak, Premk 2001: 61-62): npr. Criftus ie od fuih fnanceu inu deshelanou fashpotouan (TE 1555, A7b).

2 Ženski členi parov se (razen spolske razlike) lahko pomensko prekrivajo z moškimi, pogosto pa se od njih tudi razlikujejo (Merše 2007: 116-118). Poimenovanji besednik in besednica se glede označevane dejavnosti ('govoriti komu v korist', 'zagovarjati koga') izhodiščno nanašata na isti konkretni osebi: besednik na Kristusa kot božjega sina, redkeje uporabljena besednica pa na Marijo kot Kristusovo oz. božjo mater: npr. aku pag du grefhi taku imamo aniga oduetnika oli befednika per tim ozhetu Iefufa Chriftufa prauizhniga (TC 1550: 104 (60b)). Ista nanašalnost velja za večino izpričanih rab odvetnika in za obe pojavitvi odvetnice. Raba kaže, da so bile Kristusove oblike pomoči grešnim ljudem motivacija številnih izglagolskih poimenovanj (npr. Vi fte lubi inu perietni Bogu, fabfton, fa volo Iefufa nashiga Odreshenika, Oduetnika inu Beffednika (TT 1560: ea); Glih taku tiga Boshyga Synu periafen imamo mi tudi kferci veti, kir ie ta veliki teshki ferd Boshy vfel na Je fa nasho uolo, inu poftal nash Plazhnik, Odreshenik, Spraulauiz, Beffednik inu Ifuelizhar (TR 1558: I2a)), ${ }^{55}$ ki so v ženski obliki redkeje označevalna tudi za Marijo (npr.: Diuiza Maria ie ena Oduetniza, Befedniza inu Pomozhniza pred Bugõ veh tih ludi, kateri na no klyzho (TR 1558: c2a)). Primeri splošnejše nanašalnosti moškega poimenovanja in rabe v pomenih 'govornik' ali 'odvetnik' so redki: npr.

Taciga dopernefti na tim hudim fueitu nigdar oben Ceffar, ne Kral, ne Viuda /.../ shnih kunshtnimi inu vuzhenimi beffedniki /... / ne fo premogli (TR 1558: Z3b); POtle zhes pet dni ulezhe doli Ananias ta Vifshifar fteimi Starishi, inu fteim Tertulló Befednikom (TT 1557: 413). ${ }^{56}$

Pomen je prepoznaven po spremenjenem vršilcu dejanja, spremnih prilastkih in neredko po rabi samostalnika v množini.

Člena para obladavec - obladavka sta po enkrat uporabljena v DB 1584, oba kot del razlag lastnih imen. Obladavec je naveden v robni opombi (Iesus Nave Se rezhe en odrefhenik ali obladavez (DB 1584: II, 172a)), obladavka pa v predgovoru k Tobievim bukvam (Sara fe rezhe, ena kir fe Shtrita, ena obladauka, kir h'puflednimu premore, oblada inu doby (DB 1584: II, 147a)).

2.1 Številna moška poimenovanja, izpričana v slovenskih knjižnih izdajah 16. stoletja, ostajajo brez ženskih parov, za kar običajno obstajajo zgodovinski

55 O številnosti eno- in večbesednih poimenovanj za Jezusa Kristusa prim. Rajhman 1977: 114-115 in Legan Ravnikar 2003: 570.

${ }^{56}$ Dalmatinov prevod se od Trubarjevega le besednoredno razlikuje: npr. s'tém Befsédnikom Tertullom (DB 1584: III, 75b), Lutrov pa z izbiro nemškega ekvivalenta kaže na uresničevani pomen 'odvetnik, zagovornik' vnd mit dem Redener Tertullo (LB 1545: 2243), še določneje pa z izbiro ekvivalenta novi slovenski prevod: $\check{C}$ ez pet dni je prišel tja véliki duhovnik Hananija z nekaj starešinami in z nekim pravnikom Tertúlom (SP 1996: 1675-1676). 
in pomenski razlogi (npr. aarlahar, galjot; papež, škof; arhangel/arhanjel; arianer, antitrinitar, gerob itd.). Samo moškim vršilcem dejanj so npr. pripadala nekatera mesta v cerkveni hierarhiji (npr. papež, škof). Nekaterih poklicev in opravil v zgodovini, ki jo neposredno ali skozi biblijsko perspektivo zrcalijo dela slovenskih protestantskih piscev 16. stoletja, ženske niso opravljale (npr. nekaterih vojaških poklicev).

Brez ženskega para nadalje ostajajo:

- številna moška poimenovanja z negativno ali ekspresivno vsebino: npr. divjak, izdajicalizdavec; Taku ga Sludi klizhkakim hudim touarishem, pyanzom inu Iegerzom perpela (TC 1575: 148)). Poimenovalno so izpostavljene osebe moškega spola;

- moška poimenovanja, ki označujejo službe in položaje v cerkveni hierarhiji (npr. apostol, ebiskop (JPo 1578), superintendent, izpovednik/spovednik; tudi anžige ${ }^{57}$ ), neredko opredeljena z zgodovinskimi dejstvi (Kristus je imel dvanajst učencev - apostolov, zato žensko parno poimenovanje v okviru osnovnega pomena ni možno). Zaradi sopomenskosti naj bi isto veljalo tudi za iz nemščine prevzeti samostalnik joger, vendar ta nastopa parno z jogrinjo,${ }^{58}$ kar je omogočila pomenska širitev oz. njena pomenska oddaljitev;

- poimenovanja pripadnikov različnih skupin in sekt: antikrišt, antitrinitar, arijan (različica je zapisana v JPo 1578) in arijaner (različico navaja Trubar: npr. v Ar 1562), cvinglijaner, donatist itd.

- poimenovanja, ki se nanašajo na dejavnost konkretnih oseb moškega spola (npr. izveličar, ki se nanaša na Kristusa). Moškega spola sta poimenovanji za nevidno duhovno bitje, ki pooseblja zlo (hudič, zludi, satan), in za nevidno dobro duhovno bitje: angel in arhangel/arhanjel (JPo 1578), serafin. Hudečica, ki se enkrat samkrat pojavlja v TA 1566, je sestavina abecedno uvrščenega niza samostalnikov, ki se začenjajo na H: Hlad hudič hudezhiza (TA 1566: A3a). Zaradi posebne namembnosti seznama in nesobesedilnega navajanja primerov tudi na pomen hudečice in na okoliščine njene rabe ni mogoče zanesljivo sklepati.

2.2 Neparnih je tudi nekaj ženskih poimenovanj. Odsotnost moškega para je npr. posledica dejavnosti, ki jo lahko opravljajo le ženske: npr. ama, dojka, otročnica,${ }^{59}$ ki se rabi v pomenu 'ženska v prvih tednih po porodu'. Sobesedilne rabe ame kažejo na usmerjenost njene dejavnosti na otroke: Nefsi ga v'tvoim narozhaju, (kakòr ena Ama enu Déte no/si) (DB 1584: I, 85a). Brez moškega para se pojavlja tudi devica. Neparnost, splošna razširjenost in pogostost pojavljanja je v veliki meri posledica ustaljene povezave z Marijo kot Jezusovo

\footnotetext{
${ }^{57}$ Npr.: Mi beremo vuenih Buquah od eniga Anshigla, tu ie, od eniga kir ie fam vueni Pufzhavi oli Vgofdu (ta ie en praui Menih, en Samouvezh bil) (TAr 1562: 82b).

${ }^{58}$ Prim. slovarski sestavek jogrinja - Novak v Merše, Novak, Premk 2001: 73.

${ }^{59}$ Samostalnik ama je bil splošno rabljen, v Registru, dodanem DB 1584, pa mu je pripisana motivacijsko razvidnejša (iz glagola dojiti) vzhodnoslovenska narečna ustreznica dojka (DB 1584: III, CcIIIb).
} 
materjo. Od 26 pojavitev v DB 1584 jih je 20 v neposredni zvezi z Marijo: npr Divize Marie ozhifzhovanje (DB 1584: III, 31a). ${ }^{60}$

2.3 Brez spolnega predznaka ostajajo poimenovanja mladičev: npr. jagnje (splošno uporabljani samostalnik), jagnjič (redkeje izpričan samostalnik, pri katerem je z manjšalnim obrazilom -ič poudarjena pomenska sestavina mladosti in nedoraslosti, hkrati pa tudi majhnosti) ter narečno opredeljena glasoslovna različica agnec (v DB 1584 je navedena v tretjem registrskem stolpcu (Slovenfki, Besjazhki)).

3 Velika večina ženskih parov spada v skupino modifikacijskih tvorjenk, del tovrstnih poimenovanj pa izkazuje nadomestno osnovo (npr. sin - hči). Moški členi parnih poimenovanj so praviloma pogosteje rabljeni kot ženski.

3.1 Bohoriču je uspelo $\mathrm{z}$ omembo izpeljave $\mathrm{z}$ obrazili $-i c a$, $-i n j a,-k a^{61} \mathrm{v}$ slovnici povzeti osnovne tvorbene modele ženskih parnih poimenovanj. Zaporedje zrcali tudi pogostnostno razvrstitev v tedanji knjižnojezikovni praksi. Osnovni tvorbeni model je: moško poimenovanje + -ica (npr. mlinar - mlinarica) s substitucijskim podtipom (npr. bojnik - bojnica, kjer gre za nadomestitev obrazila -ik z -ica). Obstajajo tudi obrobnejši modeli: bog - boginja, kruhapek - kruhapekinja; firšst - firština; boter - botra. Tudi če je moško poimenovanje prevzeto in brez razvidne obrazilne podomačitve, se ženski pari izpeljujejo $\mathrm{z}$ domačimi obrazili, najpogosteje z -ica, -inja se pojavlja le izjemoma (npr. žnidar - žnidarica, ajd + ajdinja).

Pogosta je parna kombinacija korensko različnih in (vsaj navidezno) tvorbeno nepovezanih poimenovanj. Zaslediti jih je mogoče v vseh pomenskih skupinah parnih poimenovanj, največ pa pri najstarejši, ki jo predstavljajo sorodstvena poimenovanja: npr. sin - hči, hlapčič - dečla, jelen - košuta itd. Parno npr. nastopata tudi flegar in ama, čeprav ju povezuje le eden izmed obrobnejših pomenov: »Krali / Kralice / Vyudi / Gofposzhina / Imaio slushiti Bogu /... to Cerkou braniti / te Cerque Flegary inu Ame biti« (TAr 1562: 41b).

3.1.2 Spremni pojav pogosteje rabljenih moških poimenovanj je tudi izpričanost večje glasoslovne in besedotvorne variantnosti. Prvo lahko povzroči izguba zvenečnosti ali izgovorno slabljenje nenaglašenih samoglasnikov (npr. norec/norc), druga pa je značilnost številnih prevzetih samostalnikov. Pri istokorenskih ženskih členih parov je najpogosteje spremenljiv morfemskostični del: Npr. doktar/doktor - doktorca; lotar/loter - lotrica/lotrca; kramar/kramer - kramarica, premeno po palatalizaciji izkazujeta para volk - volčica, knez kneginja. Primeri večje glasoslovne spremenljivosti ženskega para so redkejši: npr. ošter - oštericaloštarica.

3.2 Uveljavljenost $\mathrm{v}$ živi in v knjižnojezikovni rabi je spodbujala $\mathrm{k}$ tvorbi novih členov besedne družine (npr. golob $\rightarrow$ golobec, golobič, golobar, golobji,

${ }^{60} \mathrm{O}$ terminoloških in neterminoloških pomenih samostalnikov dečla in devica (tudi zveze devica Marija) prim. Legan Ravnikar 2003: 569.

${ }^{61}$ Bajec (1950: 94-95) navaja, da z obrazilom - $k a$ delamo iz moških imen ženska. Obrazilo $-k a$ ustreza obraziloma $-e k$ in $-e c$, s katerima tvorimo moška poimenovanja. 
golobinji; cesar + cesarjev(cesarjov). Poleg pridevnikov so se v razširjene besedne družine neredko uvrščale tudi manjšalnice: npr. doktar/doktor $\rightarrow$ doktorčič, doktor(i)ca. Podaljšani besednodružinski tvorbeni niz izjemoma izkazuje tudi devica: npr. devica $\rightarrow$ devičen, devičica.

3.3 Primerjava izpričanih pomenov moškega in ženskega člena para kaže, da je ženska različica lahko uresničevala več pomenov ali se pomensko celo razlikovala od moškega para. ${ }^{62}$ Najbolj značilna pomenska oddaljitev od poimenovanj moškega spola nastaja tedaj, kadar ženske nastopajo le kot nosilke pomena 'žena vršilca poklicne dejavnosti'. Ker pa običajno tudi same opravljajo isto (ali podobno) poklicno dejavnost kot njihovi zakonci, ta pomen praviloma ni edini.

Tako moška kot ženska poimenovanja so pogosto rabljena tudi v neosnovnih pomenih. Ker so moška poimenovanja pogosteje rabljena, so tudi njihove rabe v prenesenih pomenih bolj opazne: npr. »One [= ptizhize] imajo eniga bogatiga kuharja inu kluzharja, timu je ime ta ozha v'Nebi, ta ima eno Kuheinio, katera je taku Shiroka, kakor je ta Svejt« (TPo 1595: II, 227).

Ekspresivno je poimenovanje človeka z živalskim imenom: O tvoiga molenia ti Hudizhova prekleta Lefiza. On [= Erodež] dela kakòr ena kunftna prav Lefiza (KPo 1567: LVb). Razmerje med Kristusom in krščansko skupnostjo je primerjano $\mathrm{z}$ razmerjem med ženinom in nevesto. Npr.:

Gdo ie Shenin? Iesus Chriftus Syn Boshij (JPo 1578: III, 107b) - Gdo ie ta Neuefta? Sueta Karfzhanska Catoliska Cerkou (JPo 1578: III, 107b). Živalska imena ženskega spola so zajeta tudi v primere: npr. ficer gredo ty ludje v Pridigo inu is pridige, kakor krave (TPo 1595: II, 17). ${ }^{63}$

3.4 Tako moška kot ženska poimenovanja so pogosto členi spolsko poenotenih naštevalnih nizov. Iz različnih razlogov prevladujejo nizi moških poimenovanj (ker se le-ta pogosteje pojavljajo, ker so številna dejanja značilna samo zanje, ker so običajnejši tudi v vlogi univerzalnih poimenovanj): npr.

Kei vidish da bi fe Krally, Firfti Papesh, Cardinali, Ebifcopi, Korrary \&c. takouega Vka darshali? (JPo 1578: II, 67b); Ter vfaj jeft neifem offertovala, ni truzala, inu fim vfai vezh imejla, kakor ti Cefsariza inu Krajliza (TPo 1595: III, 126).

Mešane nize praviloma pričenjajo členi moškega spola. $V$ prevedenih delih je zaporedje določeno s prevodno predlogo, v samostojnejših delih (npr. v TC 1575) pa so pisci ravnali enako. Npr.: »Inu S. Paul zheftu grofouitu zhes vee

${ }^{62} \mathrm{Na}$ različen spekter dolžnosti je npr. mogoče sklepati na osnovi sobesedilnih omemb vratarja in vratarice, saj je vratar lahko opravljal službo tudi pri mestnih vratih, vratarica pa domnevno le pri hišnih: Ta ifti ie shal Siesufom na Palacio alli Duor velikiga Faria /... inu ie gouoril Suratarizo, inu ie pelial Petra notar (JPo 78: I, 120a).

${ }^{63} \mathrm{O}$ metaforičnih pomenskih prenosih v okviru pomenske skupine o živalih, ki potekajo v smeri žival $\rightarrow$ človek s kako lastnostjo, prim. Novak 2004: 81, o živalih kot sestavnih delih primerjav pa v Novak 2004: 226. 
Preshushnike, Curbarie, Preshushnice, Curbe inu zhes te, kir vnezhiftofti prebiuaio /.../ gouori« (TC 1575: 387-388).

VIRI

BH 1584 = Bohorič, Adam, 1584: Arcticae horulae fuccifivae. Wittenberg.

DB 1584 = Dalmatin, Jurij, 1584: BIBLIA, TV IE VSE SVETV PISMV, STARIGA inu Noviga Teftamenta. Wittenberg. Faksimile, 1968. Ljubljana: Mladinska knjiga v Ljubljani v sodelovanju z založbo Dr. Trofenik v Münchnu.

JPo 1578 = Juričič, Jurij, 1578: POSTILLA, To ie KERSZHANSKE EVANGELSKE predige. Ljubljana.

KPo 1567 = Krelj, Sebastijan, 1567: POSTILLA SLOVENSKA. Regensburg.

LB 1545 = Luther, Martin, 1545: Die gantze Heilige Schrifft. Wittenberg.

LH 1566 = Luther, Martin, 1566: Haußpoftill I-III. Nürnberg.

MD 1592 = Megiser, Hieronymus, 1592: DICTIONARIVM QVATVOR LINGVARVM. Graz.

MTh 1603 = Megiser, Hieronymus, 1603: Thefaurus Polyglottus vel, Dictionarium Multilingue. Francofurti ad Moennum.

PS 1894-1895 = Pleteršnik, Maks, 1894-1895: Slovensko-nemški slovar I (A-O, 1894), II (P-Ž, 1895). Ljubljana.

SA 1559 = Spangenberg, Iohannes, 1559: Außlegung der Epistel vnd Euangelien . Nürnberg.

SP 1996 = Sveto pismo stare in nove zaveze, 1996. Ljubljana.

TA $1550=$ Trubar, Primož, 1550: Abecedarium vnd der klein Catechifmus. Tübingen.

TA 1555 = Trubar, Primož, 1555: ABECEDARIVM. Tübingen.

TA 1566 = Trubar, Primož, 1566. ABECEDARIVM, OLI TABLIZA. Tübingen.

TAr 1562 = Trubar, Primož, 1562: ARTICVLI OLI DEILI, TE PRAVE STARE VERE KERSZHANSKE. Tübingen.

TC 1575 = Trubar, Primož, 1575: CATEHISMVS SDVEIMA ISLAGAMA. Tübingen.

TE 1555 = Trubar, Primož, 1555: TA EVANGELI SVETIGA MATEVSHA. Tübingen.

TkM 1579 = Tulščak, Janž, 1579: Kerfzhanske LEIPE MOLITVE. Ljubljana.

TO 1564 = Trubar, Primož, 1564: CERKOVNA ORDNINGA. Tübingen.

TPo 1595 = Trubar, Primož, 1595: HISHNA POSTILLA. Tübingen.

TPs 1566 = Trubar, Primož, 1566: Ta Celi Pfalter Dauidou. Tübingen.

TR 1558 = Trubar, Primož, 1558: EN REGISHTER. Tübingen.

TT 1557 = Trubar, Primož, 1557: TA PERVI DEIL TIGA NOVIGA TESTAMENTA. Tübingen. 
TT 1560 = Trubar, Primož, 1560: TA DRVGI DEIL TIGA NOVIGA TESTAMENTA. Tübingen.

TT 1577 = Trubar, Primož, 1577: NOVIGA TESTAMENTA PVSLEDNI DEIL. Tübingen.

TT 1581-82 = Trubar, Primož, 1581-82: TA CELI NOVI TESTAMENT. Tübingen.

ZK 1595 = Znojilšek, Janž, 1595: KATECHISMVS DOCTORIA MARtina Luthra. Tübingen.

\section{LITERATURA}

Kozma AHAČIČ, 2007: Zgodovina misli o jeziku in književnosti na Slovenskem: protestantizem. (Zbirka Linguistica et philologica 18). Ljubljana: Založba ZRC, ZRC SAZU.

Anton BAJEC, 1950: Besedotvorje slovenskega jezika. I Izpeljava samostalnikov. Ljubljana: Slovenska akademija znanosti in umetnosti, Razred za filološke in literarne vede (Dela - Opera 1).

France BEZLAJ, 1995: Etimološki slovar slovenskega jezika. III/P-S. Dopolnila in uredila Marko Snoj in Metka Furlan. Ljubljana: Slovenska akademija znanosti in umetnosti (izd.), Mladinska knjiga (zal.).

Anton GRABNER - HEIDER, Jože KRAŠOVEC, s sodelavci, 1984. Biblični leksikon. Celje: Mohorjeva družba.

Andreja LEGAN RAVNIKAR, 2003: Oblikovanje obredne terminologije v okviru normiranja slovenskega knjižnega jezika. Vidovič Muha, Ada (ur.): Slovenski knjižni jezik - aktualna vprašanja in zgodovinske izkušnje. Metode in zvrsti. Obdobja 20. Ljubljana: Center za slovenščino kot drugi/tuji jezik pri Oddelku za slovenistiko Filozofske fakultete Univerze v Ljubljani. 563-580.

- -, 2007: O konverziji kot postopku knjižne (terminološke) tvorbe pri slovenskih protestantskih piscih 16. stoletja. Riječ 13/2. 108-127.

Majda MERŠE, 2007: Prikaz poklicnih dejavnosti v delih slovenskih protestantskih piscev 16. stoletja. Jesenšek, Marko (ur.): Besedje slovenskega jezika (Zora 50). Maribor: Slavistično društvo. 99-126.

Majda MERŠE, France NOVAK, Francka PREMK, 2001: Slovar jezika slovenskih protestantskih piscev 16. stoletja. Poskusni snopič. Ljubljana: Založba ZRC, ZRC SAZU.

Jožica NARAT, 1996: Izrazi za 'učenec' pri slovenskih protestantskih piscih. Jakopin, Franc, Kerševan, Marko, Pogačnik, Jože (ur.): III. Trubarjev zbornik. Ljubljana: Slovenska matica v Ljubljani, Slovensko protestantsko društvo Primož Trubar. 263-272.

Jožica NARAT - ŠREKL, 1991: Samostalniške besednozvezne sopomenske v Dalmatinovi Bibliji. Müller, Jakob, Weiss, Peter (ur.): Jezikoslovni zapiski 1. Zbornik 
Inštituta za slovenski jezik Frana Ramovša. Ljubljana: Inštitut za slovenski jezik Frana Ramovša. 63-72.

France NOVAK, 2001: Kako so protestantski pisci 16. stoletja poimenovali nove pojme. Kerševan, Marko (ur.): 450-letnica slovenske knjige in slovenski protestantizem. Ljubljana: Slovensko protestantsko društvo Primož Trubar in Znanstveni inštitut Filozofske fakultete. 103-120.

- -, 2004: Samostalniška večpomenskost v jeziku slovenskih protestantskih piscev 16. stoletja. (Zbirka Linguistica et philologica). Ljubljana: Založba ZRC SAZU, ZRC SAZU.

Martina OROŽEN, 1996: Poglavja iz zgodovine slovenskega knjižnega jezika (od Brižinskih spomenikov do Kopitarja). Ljubljana: Filozofska fakulteta, Univerza v Ljubljani, Oddelek za slovanske jezike in književnosti.

Breda POGORELEC, 1997: Slovenska skladnja in poimenovanja ženskih oseb. Derganc, Aleksandra (ur.): XXXIII. seminar slovenskega jezika, literature in kulture. Ljubljana: Univerza v Ljubljani, Filozofska fakulteta, Oddelek za slovanske jezike in književnosti. Dodatek, 1-9.

Jože RAJHMAN, 1977: Prva slovenska knjiga v luči teoloških, literarno-zgodovinskih, jezikovnih in zgodovinskih raziskav. Ljubljana: Partizanska knjiga.

Jože TOPORIŠIČ, 1987: Zimske urice, prva slovenska slovnica. Bohorizh, Adam: Arcticae horulae succisivae, Zimske urice proste. Maribor: Založba Obzorja. 281-328.

Ada VIDOVIČ MUHA, 1986: Neglagolske tvorjenke v Trubarjevi Cerkovni ordningi. Pogorelec, Breda (ur.): 16. stoletje v slovenskem jeziku, književnosti in kulturi. Obdobja 6. Univerza Edvarda Kardelja v Ljubljani, Filozofska fakulteta, Znanstveni inštitut, Oddelek za slovanske jezike in književnosti. 349-374.

- -, 1997: Prvine družbene prepoznavnosti ženske prek poimenovalne tipologije njenih dejavnosti, lastnosti. Derganc, Aleksandra (ur.): XXXIII. seminar slovenskega jezika, literature in kulture. Ljubljana: Univerza v Ljubljani, Filozofska fakulteta, Oddelek za slovanske jezike in književnosti. 69-79.

Listkovno gradivo Sekcije za zgodovino slovenskega jezika Inštituta za slovenski jezik Frana Ramovša, ZRC SAZU, zbrano s popolnimi izpisi del slovenskih protestantskih piscev 16. stoletja.

\section{SUMMARY}

Designation needs that became apparent when translating Biblical and other religious texts, and in composing more independent works that were more or less bound by translational conventions, encouraged $16^{\text {th }}$ century Slovenian Protestant writers to look for and to form feminine pairs of masculine designations (proper and common name designations). References in the Grammar Book by Bohorič show that the feminine forms in linguistic use at the time were used as a special wordformational and semantic category. In various parts of the grammar book, pairs like 
kojn - kojnka (Rols - RöIIin), lev - levinja, psič - psičica or psička, Lamberger / Lambergar - Lambergarica, Lublančič - Lublančica or Lublanšica express the most productive formational models of feminine pairs in $16^{\text {th }}$ century standard Slovenian. These examples reflect derivation from proper and common name masculine designations, formation from a loan word and a native noun, derivation with formation specialised affixed morphemes (e.g. -ica, -inja, $-k a$ ), and phonetic conversion at the affix connection or without it.

Even though feminine pairs do not accompany all masculine designations, they can, however, be divided into two basic groups: rare proper name designations like Egipter - Egipterica, and numerous common name designations which can be grouped into different subgroups. These include pairs of profession designations (apotekar - apotekarica, kruhapek - kruhapekinja, mlinar - mlinarica) or simply designations referring to executors of various activities (besednik-besednica), pair designations referring to social structure (cesar-cesarica, kralj-kraljica, kraljič - kraljičica, firšt - firština), pair designations of family and other relations (brat - sestra, oča - mati, preded - prebaba, sin - hči; boter - botra), animal designations (golob-golobica), etc. Most feminine pairs belong to a group of modification compounds, a part of which has a substitute stem (sin - hči). Masculine elements in pair designations are more frequently used than feminine elements with standard language and living language usage, encouraging the formation of new elements of the word family (cesar + cesarjev / cesarjov). Feminine pairs can (apart from the difference in gender) have semantic equivalents to masculine pairs, but frequently differ from them.

Numerous masculine designations in $16^{\text {th }}$ century publications in Slovenian did not have their equivalent feminine pairs, usually due to historic or semantic reasons (aar / ahar, galjot; papež; arianer, antitrinitar, cvinglijaner) Also, a few feminine designations were without masculine equivalents, because the profession was restricted to women (ama, dojka). 